University of Nebraska - Lincoln

DigitalCommons@University of Nebraska - Lincoln

1958

\title{
The Experimental Histopathology of the "Tumor" on the Brain of the Stickleback Caused by Diplostomum baeri eucaliae Hoffman and Hundley, 1957 (Trematoda: Strigeoidea))
}

\author{
Glenn L. Hoffman \\ US Fish and Wildlife Service \\ James B. Hoyme \\ University of North Dakota
}

Follow this and additional works at: https://digitalcommons.unl.edu/usfwspubs

Part of the Aquaculture and Fisheries Commons

Hoffman, Glenn L. and Hoyme, James B., "The Experimental Histopathology of the "Tumor" on the Brain of the Stickleback Caused by Diplostomum baeri eucaliae Hoffman and Hundley, 1957 (Trematoda: Strigeoidea))" (1958). US Fish \& Wildlife Publications. 98.

https://digitalcommons.unl.edu/usfwspubs/98

This Article is brought to you for free and open access by the US Fish \& Wildlife Service at DigitalCommons@University of Nebraska - Lincoln. It has been accepted for inclusion in US Fish \& Wildlife Publications by an authorized administrator of DigitalCommons@University of Nebraska - Lincoln. 


\title{
THE EXPERIMENTAL HISTOPATHOLOGY OF THE “TUMOR” ON THE BRAIN OF THE STICKLEBACK CAUSED BY DIPLOSTOMUM BAERI EUCALIAE HOFFMAN AND HUNDLEY, 1957 (TREMATODA: STRIGEOIDEA)
}

\author{
Glenn L. Hoffman* and James B. Hoyme
}

\section{Bacteriology Department, University of North Dakota, Grand Forks, North Dakota}

The structure of the "tumor" on the brain of the stickleback fish, Eucalia inconstans (Kirtland) caused by Diplostomum baeri eucaliae, has been briefly reported (Hoffman and Hoyme, 1957 ; Hoffman and Hundley, 1957) and consists of an outgrowth of the columnar epithelium of the choroid plexus which surrounds the metacercariae at the postero-lateral aspect of the optic lobes. The present report deals with the experimental development of the "tumor."

No record of a comparable structure in fish could be found and the reader is referred to our earlier paper (Hoffman and Hundley, 1957) for further introduction, and materials and methods.

\section{CONTROL}

In the uninfected fish the choroid plexus is a relatively small sack-like structure lined by columnar epithelium, located at the postero-lateral aspect of the optic lobes (Figs. 1, 2). Its anterior border appears to originate from, or at, the posterior side of the nucleated layer of the optic lobe. Its posterior border appears to originate from, or at, the valvula cerebelli; the meninges are very thin. Its function is the secretion of cerebrospinal fluid.

\section{LOCATION OF THE METACERCARIAE}

Twenty-eight sticklebacks, experimentally infected for various lengths of time were fixed, serial sectioned, and studied. The following data, converted to percentages, represent a summary of spot checking, i.e. ca every fifth section was studied. The worms in all tisues were counted, but for brevity the negative counts are omitted.

1. 15 to 35 minutes-Subcutaneous tissue 52 ; gills 22 ; muscle 13 ; blood vessels 6 ; skin 5 ; viscera 1 ; oral epithelium 0.5 ; brain ventricles 0.25 . Of 10 worms counted in one fish 9 were in the head region.

2. 1 hour and 40 minutes to 3 hours and 20 minutes-Subcutaneous tissue 45 ; muscle 25 ; skin 13; blood vessels 10 ; gills 2 ; fins 2 ; viscera 2 ; optic lobes 0.6 ; large cranial nerves 0.3 .

3. 5 to 28 hours-Choroid plexus 72.2 ; submeningeal 6.7; eye (sclera and cornea) 6; medulla 5.1 ; optic nerve 2.3 ; connective tissue 2.3 ; just anterior to the optic lobes 2 ; tissue of optic lobes 2 ; ventricles of optic lobes 0.7 ; just posterior to the brain 0.7 .

4. 3 days-Choroid plexus and ventricles 50 ; tissue of optic lobes 26 ; submeningeal 10 ; cerebellum 10; cranial nerves 3 ; medulla 1 .

5. 6 to 8 days-Choroid plexus and ventricles 47 ; optic lobes 24 ; submeningeal 15 ; cranial nerves 5 ; medulla 4 ; cerebellum 2 ; central aqueduct of brain 2 ; vitreous chamber of eye 1 .

6. 10 days-Choroid plexus and ventricles 70 ; optic lobes 24 ; submeningeal 3 ; central aqueduct of brain 2 ; olfactory lobes 0.4 .

Received for publication December 30, 1957.

Supported in part by research grant B-855 from the Institute of Neurological Diseases and Blindness of the National Institutes of Health, Public Health Service

* Present address : Eastern Fish Disease Laboratory, Leetown (P. O. Kearneysville), West Virginia. 
7. 22 to 35 days-Choroid plexus "sack" and ventricles 92 ; olfactory lobes 5 ; optic lobes 1 ; central aqueduct of brain 0.5 ; vitreous chamber of eye 0.4 ; cerebellum 0.2 ; pons 0.2 .

8. 50 to 60 days-Choroid plexus "sack" and ventricles 96 ; vitreous chamber of eye 2 ; olfactory lobes 0.6 ; cerebellum 0.6 .

These data indicate that the cercariae penetrate the skin, perhaps in greater numbers in the head region and particularly the gills, migrate through subcutaneous tissue and muscle, and some, at least, enter blood vessels to make their way to the brain region. This is in accord with the findings of the migration of Diplostomum spathaceum by Ferguson (1943) and Posthodiplostomum minimum centrarchi by Hoffman (1958). A smaller number probably enter the brain directly through the soft parts of the cranium, or by route of the cranial nerves. Subsequently the metacercariae are found under the meninges, in the nervous tissue of the brain itself, particularly the optic lobes, and in the ventricles. Eventually many of them migrate to the choroid plexus at the postero-lateral aspect of the optic lobes where a space exists between the brain and the cranium which allows growth of the "tumor."

\section{EXPERIMENTAL HISTOPATHOLOGY}

3 days (Figs. 3, 4): Most of the metacercariae which have reached the brain have localized in 2 main areas, the choroid plexus and the ventricles of the optic lobes. A few remain in the tissue of the optic lobes and just beneath its meninges. There is no evidence of hyperplasia or granulomatous reaction, but resorption of tissue damaged by migrating larvae can be seen. In heavy infections there is considerable hemorrhage postero-lateral to the brain, and behind the eyes.

11 days (Figs. 5-7) : At this time the metacercariae, with very few exceptions, are within the choroid plexus or the connecting ventricles of the optic lobes. The columnar epithelium of the choroid plexus has grown to accommodate the growing larvae, and in moderate to heavy infections it extends postero-lateral from the optic lobe. There is a depression in the roof of the cranium which allows freedom for growth of this "tumor-like" structure. The epithelium is thickened and hyperplastic in some places (Fig. 7) and the entire structure is filled with cells which appear to be macrophages (Figs. 6,7) ; these surround the worms, each of which may move freely within a restricted area. We assume that the larvae eat these cells because cellular elements can be seen in the ceca and there is no other type of cell in this structure.

42 to 50 days (Figs. 8, 9): There is no appreciable change in pathology, but it is interesting to note that heavily infected fish may survive. The "tumor-like" structure at this time shows no change, but in heavily infected fish there are also many larvae in the tissue of the optic lobes. From the examination of many cross sections it appears that these have migrated through the ependyma into the central white matter. Here there is great loss of brain tissue (Fig. 8) but the ependyma becomes hyperplastic and folds of it partly encircle the worms. Macrophages are also present, particularly in the ventricles. Although there is considerable loss of brain tissue, apparently due to resorption, in heavily infected fish, no impairment of reflexes was noted. When death due to parasites did occur it was probably due to extensive damage and subsequent hemorrhage (Hoffman and Hundley, 1957).

\section{SUMMARY}

Stickleback fish, Eucalia inconstans, were experimentally infected with the cercariae of Diplostomum baeri eucaliae, and the localization of the metacercariae and 
the histopathology were studied at intervals up to 50 days. A large majority of the worms localize within the choroid plexus and the optic lobes. The choroid plexus becomes hyperplastic and, in heavy infections, becomes a rather large "tumor-like" structure which extends postero-laterally from the optic lobes; it consists of a substantial amount of columnar epithelium with cells which appear to be macrophages surrounding the worms. Many worms also localize in the inner part of the optic lobes where considerable brain tissue is resorbed followed by hyperplasia of the ependyma and the accumulation of cells appearing to be macrophages.

\section{ACKNOWLEDGMENTS}

We wish to thank Dr. A. K. Saiki, Pathology Department and Dr. T. Snook, Anatomy Department, University of North Dakota, for interpretations and proofreading the manuscript, and the following for technical assistance or interpretations: James B. Hundley, North Dakota Public Health Department, Miss Kathleen Pigott, Antigua, British West Indies; and Drs. W. A. Wasdahl and J. D. Cardy of the Pathology Department, University of North Dakota.

\section{References Cited}

Ferguson, M. S. 1943 Migration and localization of an animal parasite within the host. J. Exp. Zool. 93: 375-399.

Hofrman, G. L. 1958 Experimental studies on the cercaria and metacercaria of a strigeoid trematode, Posthodiplostomum minimum. Exper. Parasitol. 7 (1) : 23-50.

and Hoyme, J. B. 1957 The histopathology of the "tumor" on the brain of the stickleback caused by Diplostomum baeri eucaliae Hoffman and Hundley, 1957. J. Parasitol. 43 (5) Sect. 2: 33.

and Hundeey, J. B. 1957 The life-cycle of Diplostomum baeri eucaliae n. subsp. (Trematoda: Strigeida). J. Parasitol. 43 (6) : 613-627.

\section{Explanation of Figures}

FIGURE 1. Frontal section of the brain of an uninfected stickleback. $\times 32$.

FIgURE 2. As Figure 1. $\times 100$.

FIGURE 3. Frontal section of the brain of a 3-day post-infection stickleback. $\times 32$.

Figure 4. As Figure 3. $\times 100$.

FIGURE 5. Sagittal section of the brain of an 11-day post-infection stickleback. Note that most of the "tumor" is external to the brain. $\times 32$.

Figure 6. As Figure 5. $\times 430$.

FIGURE 7. As Figure 5. Note macrophages and hyperplastic epithelium. $\times 430$.

Figure 8. Frontal section of the brain of a 42-day post-infection stickleback. Note that metacercariae are present in the internal white matter of the optic lobes as well as in the "tumor." $\times 32$.

FIgURE 9. Frontal section of the brain of a 50-day post-infection stickleback. Note that a part of the "tumor" is external to the brain. $\times 100$.

\section{Abrreviations}

\author{
Cerebel.-Cerebellum \\ Chor. pl.-Choroid plexus \\ Epith.-Hyperplastic epithelium \\ Macro.-Macrophage \\ Med.-Medulla \\ Meta.-Metacercaria (e)
}

\author{
Olf. lobe-Olfactory lobe \\ Opt. lobe-Optic lobe \\ "Tumor"-Tumor-like cyst of \\ hyperplastic epithe- \\ lium and macrophages \\ containing metacer- \\ cariae.
}




\section{Plate I}

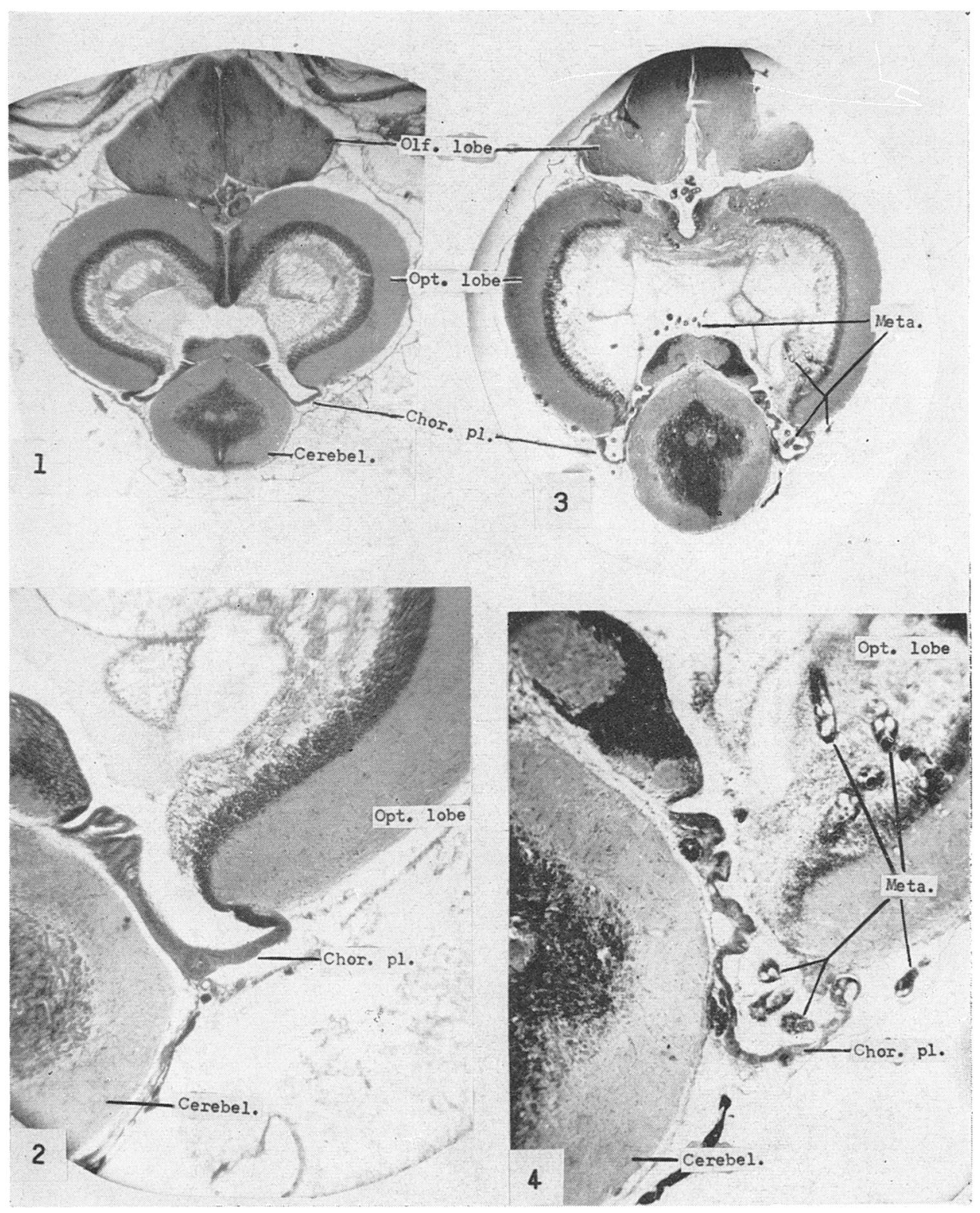




\section{Plate II}

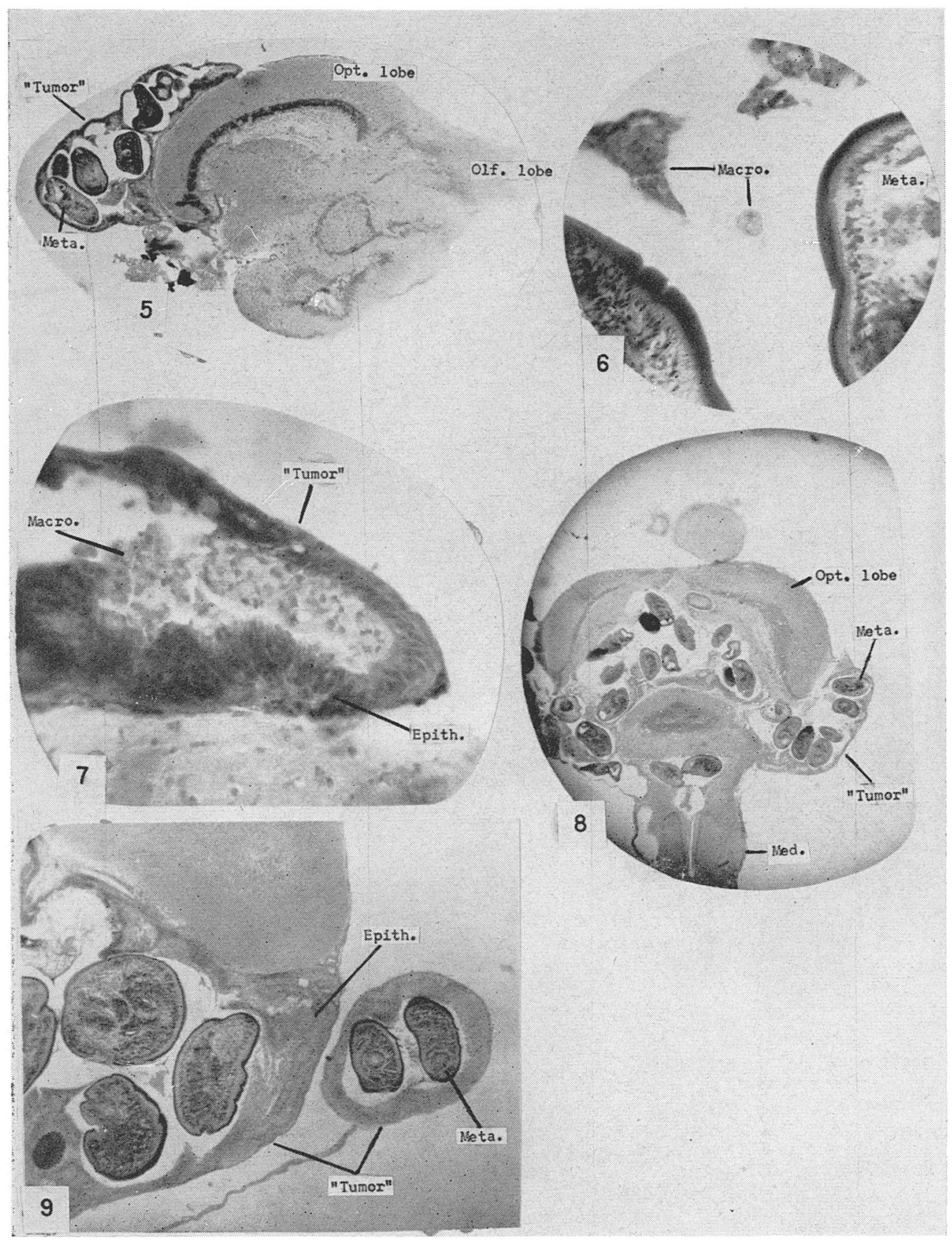

